\title{
Design of the inverter for driving CCFL
}

\author{
Ho-Ik Jun ${ }^{1 *}$ and Hyun-Seob Cho ${ }^{2}$ \\ ${ }^{1}$ Department of Non-Commissioned Officer, Hyejeon College \\ ${ }^{2}$ Department of Electronics Engineering Chungwoon University \\ 냉음극 방전 램프 구동용 인버터 설계 \\ 전호익 ${ }^{1 *}$, 조현섭 ${ }^{2}$ \\ ${ }^{1}$ 혜전대학교 전문사관과, ${ }^{2}$ 청운대학교 전자공학과
}

\begin{abstract}
Piezoelectric inverter for driving CCFL is designed in this study. Of them, CCFL is generally used because it has advantages such as small size, high efficiency and good brightness characteristics. the description of the piezoelectric effect is not present here and can be easily found in numerous publications as well as complex equations and formulae. What is the most important to understand is that "they are different" one cannot just change an electromagnetic transformer(EMT) for a piezoelectric one. The simulation program supports the modeled piezoelectric inverter for this paper and the equivalent circuit. The result of the experiment shows more than $90 \%$ improvement in terms of the efficiency.
\end{abstract}

요 약 본 논문에서는 냉음극 방전램프 구동용 압전 인버터를 설계하였다. 등가회로의 모델링 방법으로는 진동자의 모델에 많이 이용되고 있는 어드미턴스 궤적법을 사용하였고, 인버터 설계 시 전자회로 해석프로그램인 PSIM을 사용하여 압전 인버 터 설계에 대한 검증을 하였다. 압전기 영향의 기술은 다수의 연구에서 복잡한 방정식과 공식도 쉽게 찾을 수 있다. 특히 압전 기 세라믹 EMT가 변화하지 않으며 PT기초 전기소자의 여러 가지 예는 더욱 효과적인 PT의 강점을 이용하는데 도움이 될 것이다. 과적으로, 회로의 단순화와 그에 따른 소형화 그리고 입출력대비 효율이 최대 $90 \%$ 이상으로 우수한 성능을 보였다.

Key Words : CCFL, HCFL, Multilayer Inverter, Transformer, Piezoelectric Actuator

\section{Introduction}

In comparison with electromagnetic transformers they have some inherent features which should be kept in mind while developing schematics of inverters using CCFL. The brief comparison of two kinds of transformers is in the Table 1. Piezoelectric transformers can be used in the same applications as usual electromagnetic transformers but the most perspective are high output voltage low power applications and low output voltage, low and middle power (up to 50W) applications. Further on we will speak mostly about high-voltage piezoelectric transformers. In comparison with electromagnetic transformers they have some inherent features which should be kept in mind while developing schematics of inverters using CCFL. The most important for a circuit designer is the resonant frequency response of a PT. The factor, step-up ratio $\mathrm{N}$, resonant frequency and efficiency $\mathrm{K}$ of a PT vary with the load resistance.

This Paper was supported by research Fund of Hyejeon College in 2011

${ }^{*}$ Corresponding Author : Ho-Ik Jun(Hyejeon College)

Tel : +82-41-630-5350 e-mail: report@hyejeon.ac.kr

Received February 7, $2014 \quad$ Revised March 3, $2014 \quad$ Accepted April 10, 2014 


\section{Main features of PT}

Therefore there are two main problems facing a circuit designer. The first is that the inverter has to operate close to the resonant frequency of the PT even when the load resistance may change. It is necessary to obtain maximum step-up ratio and efficiency. The second is that maximum efficiency for a given PT (the dimensions of the PT are fixed) can be obtained only in a certain range of load resistance. In other words for different loads different PT should be developed.

[Table 1] The comparison of piezoelectric and electromagnetic transformers

\begin{tabular}{|c|c|c|}
\hline Principle & $\begin{array}{c}\text { Electromagnetic } \\
\text { induction }\end{array}$ & Piezoelectric effect \\
\hline Step-up ratio & Wound ratio & $\begin{array}{c}\text { Shape ratio(length/thickness, } \\
\text { number of layers) } \\
\text { load impedance }\end{array}$ \\
\hline $\begin{array}{c}\text { Frequency } \\
\text { response }\end{array}$ & Flat & Resonant \\
\hline $\begin{array}{c}\text { Output } \\
\text { waveform }\end{array}$ & Input waveform & Sine wave \\
\hline $\begin{array}{c}\text { Input/output } \\
\text { impedance }\end{array}$ & Inductive & Capacitive \\
\hline Device polarity & Non-polar & Pon-combustible \\
\hline Combustibility & Combustible & Over 95\% \\
\hline $\begin{array}{c}\text { Conversion } \\
\text { efficiency }\end{array}$ & About 85\% & Breaking \\
\hline Failure form & $\begin{array}{c}\text { Burning, open } \\
\text { winding }\end{array}$ & \\
\hline
\end{tabular}

The parameters of the model are usually given by the manufacturer or can be measured as shown in [1]. It should be kept in mind that this is the idealized model which is valid only in the vicinity of the resonant frequency. In fact a PT has several resonant frequencies, so-called harmonics. For every harmonic parameters of the model are different. Usually the first ( $\mathrm{so}^{-}$-called $\mathrm{N} / 2-$ mode, where $\lambda$ is the sound wavelength in ceramic) or the second ( $\lambda$-mode) harmonics are chosen, because the efficiency and step-up ratio is maximal in this case and decrease quickly with the increasing the number of a harmonic. In a practical circuit changes in drive level or load characteristics may induce "mode-hopping" that is jumping to other harmonics. So it is necessary to undertake special measures to avoid such jumping. Another important feature is the capacitive input and output impedances of PT. That means that DC current cannot flow through the input or output terminals of PT, though the equivalent circuit model shows it. The more correct model is proposed in [2] and shown at fig 1 . The result is that different topology of input driver and output rectifier is used unlike EM transformer.

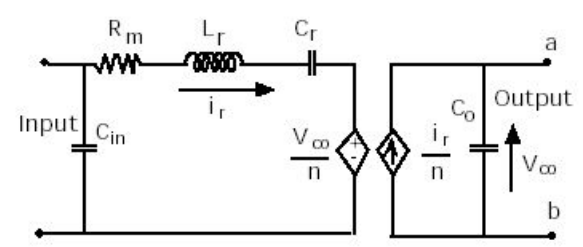

[Fig. 1] Another equivalent circuit model proposed in[2]

The input driver includes an inductor as a rule. Another reason for this inductor is to match the driver with a PT for maximum efficiency as shown in [3]. The output rectifier which is usually built as a voltage multiplier must contain even number of diodes. Finally it's important that PT has polarity. That means that if the input voltage contains DC component, like in the case of single-ended driver fig 2, it is necessary that positive DC polarity be applied to the " + " electrode of PT. Otherwise the output voltage significantly decreases. Generally it is better to avoid applying DC voltage to PT. In the case of sine input voltage (no DC component) the polarity of PT does not matter.

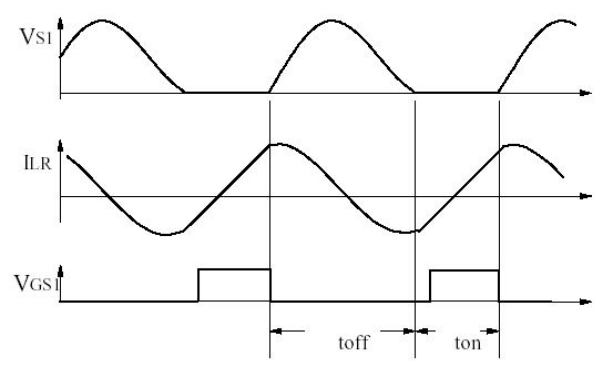

[Fig. 2] Single-ended driver wave forms (note that PT input voltage Vs1 contains DC component) 


\section{Design of piezoelectric inverter for driving LCD backlight}

All high-voltage applications of PT may be divided into two groups. The first group has relatively high load resistance - more than tens and hundreds mega ohms. It is typical for image intensifier tubes, ionizers, air cleaners, low power ozone generators, photo multipliers, laser printers and so on. The output voltage can be $1^{\sim}$ $6 \mathrm{kV}$ and the load current not more than $0,1 \sim 0,5 \mathrm{~mA}$. Another group are relatively "high-current"power supplies with output current several milli amps and output voltage $300 \sim 600 \mathrm{~V}$. And the typical value of load resistance is $100 \sim 300 \mathrm{kOhm}$. The most popular application of PT nowadays is low profile power supplies for CCFL (cold cathode fluorescent lamp) backlight of LCD displays. Typical specifications of such kind of inverter are in the Table 2 [2]. To achieve the maximum efficiency the piezoelectric transformer must be developed specially for every value of load (a lamp type). The step-up ratio is relatively small in this case $\left(5^{\sim} 10\right)$ and the $\mathrm{Q}$-factor is minimal.

Speaking about the first group of applications the easiest and cheapest way is to use a self-oscillating circuit like shown at Fig. 3. The positive feedback is provided by capacitive antenna. The inductor L1 should be matched to obtain the maximum output voltage.

\section{Simulation Study}

To improve the load characteristic of a PT-based inverter a push-pull or totem-pole drivers can be used. In this case the input voltage of PT is almost sine which also improves the efficiency. The circuit shown at the fig 3 includes the push-pull drive stage and the pre-amplifier built on the CMOS gates (CD4069). Another feature of this inverter is the varistor $\mathrm{Z} 1$ which is used for the stabilizing of the output voltage. As its capacitance is high enough (about $100 \mathrm{pF}$ ) there is no need in a capacitor connected to the Vout/2 output.

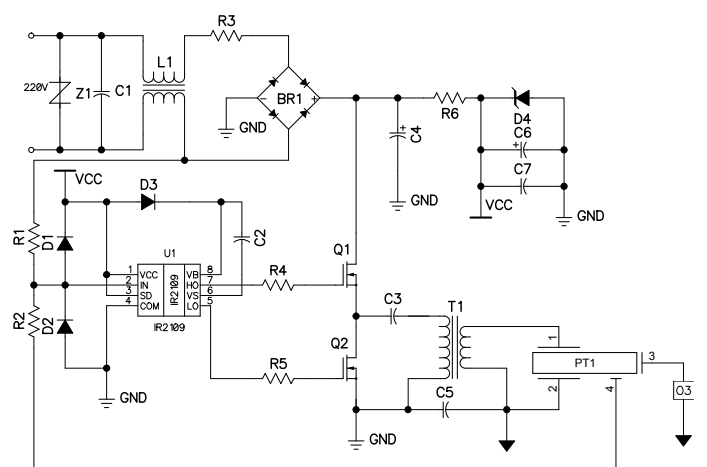

[Fig. 3] Push-pull inverter for air cleaner

The pre-amplifier together with the high-side driver is built on the IR2109 microchip. The transformer $\mathrm{T} 1$ solves tree problems at once:

[Table 2] Typical specifications of CCFL power supplies[2]

\begin{tabular}{|c|c|c|c|c|c|c|c|c|c|}
\hline $\begin{array}{l}\text { TAMURA } \\
\text { PART NO. }\end{array}$ & $\begin{array}{l}\text { INPUT } \\
\text { VOLTAGE } \\
\text { RANGE }\end{array}$ & $\begin{array}{c}\text { CONTROL } \\
\text { VOLTAGE } \\
\text { REQUIREMENT }\end{array}$ & $\begin{array}{l}\text { IAININIUIA NO } \\
\text { LOAD OUTPUT } \\
\text { VOLTAGE }\end{array}$ & $\begin{array}{l}\text { OUTPUT } \\
\text { CURRENT }\end{array}$ & $\begin{array}{l}\text { MAXIINUM } \\
\text { OUTPUT } \\
\text { POWER }\end{array}$ & $\begin{array}{l}\text { OPERATING } \\
\text { FREQUENCY }\end{array}$ & DIMMIng & H x W $\times$ L (mm) & $\begin{array}{c}\text { Weight } \\
\text { (grams) }\end{array}$ \\
\hline HBL-0217 & $3.0 \mathrm{~V} \sim 5.5 \mathrm{~V}$ & $5 V \pm 10 \%$ & $800 \mathrm{Vrms}$ & 1.1mArms & $0.4 \mathrm{~W}$ & $160 \mathrm{KHz}$ & PROVDED & $9.0 \times 9.4 \times 103.95$ & 4.46 \\
\hline HBL-0210 & $3.0 \mathrm{~V} \sim 5.5 \mathrm{~V}$ & $5 V \pm 5 \%$ & $900 \mathrm{Vrms}$ & $1.0 \mathrm{mArms}$ & $0.38 \mathrm{~W}$ & $160 \mathrm{KHz}$ & PROVDED & $8.9 \times 9.0 \times 59.5$ & 4.14 \\
\hline HBL-0204 & $3.0 \mathrm{~V} \sim 5.5 \mathrm{~V}$ & $5 V \pm 5 \%$ & $900 \mathrm{Vrms}$ & $2.0 \mathrm{mArms}$ & $0.65 \mathrm{~W}$ & $160 \mathrm{KHz}$ & PROVIDED & $8.9 \times 9.0 \times 59.5$ & 4.14 \\
\hline HBL-0214 & $4.5 \mathrm{~V} \sim 5.5 \mathrm{~V}$ & N/A & $1200 \mathrm{Vrms}$ & 4.0mArms & $3.00 \mathrm{~W}$ & $70 \mathrm{KHz}$ & PROVIDED & $5.0 \times 12.5 \times 142.0$ & 11.90 \\
\hline HBL-0215 & $4.75 \mathrm{~V} \sim 5.25 \mathrm{~V}$ & $\mathrm{~N} / \mathrm{A}$ & $700 \mathrm{Vrms}$ & $1.5 \mathrm{mArms}$ & $0.60 \mathrm{~W}$ & $160 \mathrm{KHz}$ & PROVDED & $4.3 \times 23.0 \times 46.9$ & 3.63 \\
\hline HBL-0218 & $5.0 \mathrm{~V} \sim 10.0 \mathrm{~V}$ & $\mathrm{~N} / \mathrm{A}$ & $1080 \mathrm{Vrms}$ & $2.4 \mathrm{mArms}$ & $1.20 \mathrm{~W}$ & $160 \mathrm{KHz}$ & PROVDED & $6.4 \times 9.0 \times 56.4$ & 2.61 \\
\hline HBL-0219 & $8.0 \mathrm{~V} \sim 14.0 \mathrm{~V}$ & N/A & $1300 \mathrm{Vrms}$ & 3.0mArms & $2.20 \mathrm{~W}$ & $100 \mathrm{KHz}$ & PROVDED & $7.4 \times 13.6 \times 118.0$ & 7.97 \\
\hline HBL-0216 & $9.0 \mathrm{~V} \sim 15.0 \mathrm{~V}$ & N/A & $1250 \mathrm{Vrms}$ & $3.7 \mathrm{mArms}$ & $2.5 \mathrm{~W}$ & $100 \mathrm{KHz}$ & PROVDED & $5.0 \times 12.0 \times 138.0$ & 8.77 \\
\hline
\end{tabular}


1. It's inductance is necessary for the matching.

2. The step-down voltage ratio helps to apply necessary input voltage to the PT $\left(310 \mathrm{Vp}^{-} \mathrm{p}\right.$ is too high for the PT used).

3. It enables galvanic isolation of the ozone generator from the power line.

\section{Conclusion}

Proposed inverter is a transformer-less inverter with low. By driven in both sides, effect of stray capacitance can be reduced. Since input voltage of resonant tank is twice as high as that of full-bridge resonant inverter, to drive lamp with low is possible. Only frequency control is possible with symmetric driving method, but both duty control and frequency control are possible with asymmetric driving method, which is applicable to dimming, trim, current control and etc. From experiments with single lamp, the analysis and design are verified. Multi-lamps can be driven by current balancing method using coupled inductor. Proposed inverter is suitable for CCFL driving inverter of operates in the normal mode when the feedback compensates possible changes of output voltage or current by means of changing the operating frequency.

\section{References}

[1] Design and Analysis of Piezoelectric Transformer Converters Chih-yi Lin Dissertation submitted to the Faculty of the Virginia Polytechnic Institute and State University in partial fulfillment of the requirements for the degree of Doctor of Philosophy in Electrical Engineering. Fred C. Lee, Chair, Milan M.Jovanovic, Dan Y. Chen, Dusan Borojevic, David Gao. July 15, 2008 Blacksburg, Virginia

[2] Application Note 81 Ultracompact LCD Backlight Inverters A Svelte Beast Cuts High Voltage Down to Size Jim Williams, Linear Technology Corporation Jim Phillips, Gary Vaughn, CTS Wireless Components September 2010.

[3] Analysis and Modeling of a Piezoelectric Transformer in High Output Voltage Applications Gregory Ivensky,
Moshe Shvartsas, and Sam Ben-Yaakov* Power Electronics Laboratory Department of Electrical and Computer Engineering Ben-Gurion University of the Negev P. O. Box 653, Beer-Sheva 84105 ISRAEL

[4] Erofeev A.A., Danov G.A., Frolov V.N.//Piezoelectric Transformers and their Applications in Radio-electronics.-Moscow, "Radio I Svyaz", 2012.

\section{Ho-Ik Jun}

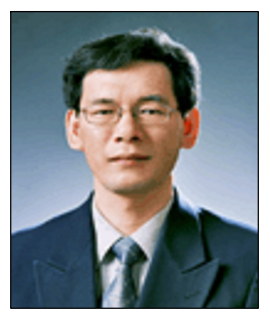

- Feb. 1986 : DanKook University Graduate School The M.E.course of the Department of Electronics

- Feb. 1998 : Dankook University Graduate School The Ph.D.course of the Department of Electronic

- Mar. 1997 Present : Hyejeon College Professor. Department of Non-Commissioned Officer.

$<$ Research Interests $>$

Factorial Automation Control, Electronics Application

\section{Hyun-Seob Cho}

[Life member]

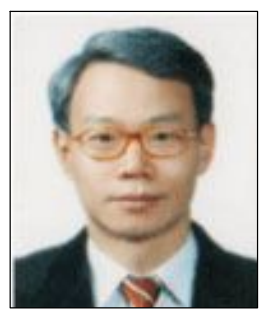

- Feb. 1990 : Wonkwang University The department of Electrical Engineering

- Feb. 1992 : Wonkwang University The M.E.course of the Department of Electrical Engineering

- Feb. 1996 : Wonkwang University Graduate School The Ph.D.course of the Department of Electrical Engineering

- Mar. 1997 Present : Chungwoon University Professor. Department of Electronic Engineering.

$<$ Research Interests $>$

Electric and Electronics Application, Automatic Control 